\title{
Rusijos gynybos pramonè: tendencijos ir perspektyvos
}

\begin{abstract}
Straipsnyje nagrinejjamos pastarojo meto Rusijos Gynybos pramonès (GPK) raidos tendencijos ir ateities perspektyvos. Pagrindinis demesys kreipiamas i šios pramonès šakos galimybes konkuruoti pasaulinėse rinkose. Parodoma, jog, nepaisant geru pastarojo meto eksporto rodiklių, pagal kuriuos Rusija yra vienas pasauliniu ginklų prekybos lyderiu, situacija šioje srityje yra nevienareikšmė. Straipsnyje parodoma, jog Rusijos gynybos pramonè dèl gilių struktūrinių problemu, didele dalimi sąlygotų SSSR paveldo bei netinkamų reformų, yra itin pažeidžiama šiuolaikinių pasaulinès ekonomikos raidos realiju akivaizdoje. Taip pat teigiama, jog GPK pavyzdys yra būdingas analizuojant Rusijos ekonomikos perspektyvas apskritai.
\end{abstract}

\section{Ivadas}

Žvelgiant i pastarojo meto Rusijos vietą pasaulyje dèmesį patraukia sẻkminga jos veikla ginklų eksporto srityje (šiuo metu pagal ginklų eksportą užima antrą vietą pasaulyje po JAV).

Gynybos pramonė yra praktiškai vienintele Rusijos ekonomikos sritis, šiuo metu sugebanti konkuruoti užsienio rinkose. Žinoma, šis konkurencingumas neretai remiasi tuo, jog pirkëjai tiesiog neturi kito pasirinkimo. Tokio technologinio lygio ginkluotęjie gali pirkti tik iš Rusijos. Tačiau ne mažiau svarbu ir tai, jog Rusijos gamybos ginkluote savo techninèmis charakteristikomis kol kas nenusileidžia, o dažnai ir lenkia vakarietiškus analogus.

Rusijos karinès pramonės kompleksas yra įdomus ir tuo, jog tai yra puiki daugumos procesu, šiuo metu vykstančių Rusijos ekonomikoje, iliustracija.

Straipsnyje yra parodoma, jog išoriškai geri Rusijos ginkluotės eksporto rodikliai slepia itin sudètingą gynybos pramonès komplekso situaciją (lygiai taip pat kaip apskritai geri Rusijos makroekonominès raidos rodikliai glaisto besikaupiančias Rusijos ekonomikos struktūrines problemas).

\footnotetext{
"Liudas Zdanavičus - Vilniaus uninversiteto Tarptautinių santykių ir politikos mokslų instituto doktorantas. Adresas: Vokiečiu 10, 01130 Vilnius, tel. 8 5 2514130.
} 


\section{Rusijos pozicijos pasaulinèje ginkluotès rinkoje}

Šiuolaikinei pasaulinei ginkluotės rinkai būdinga keletas dalyku. Visu pirma ginklų pasiūla gerokai viršija paklausą. Prekybos ginklais apimtis pastaraisiais metais itin sumažèjo. $1987 \mathrm{~m}$. pasaulinès ginkluotės prekybos apyvarta sudare 87,4 mlrd. USD, 1997 m. - 42 mlrd., o 2004 m. tik 34,8 mlrd. USD ${ }^{1}$. Pastarojo meto pasaulinès ginklu prekybos mažèjimo tendencijos daugiausiai susijusios su dalies besivystančių valstybiu, kurios yra vienos pagrindinių ginklu pirkèju, ekonominès padèties blogèjimu.

2004 m. Rusija eksportavo ginkluotės už maždaug 5,9 mlrd. USD (2005 m. planuojama tokia pat eksporto apimtis). Tai sudaro $16,9 \%$ viso ginklų eksporto (antroji vieta po JAV, kuri eksportavo ginkluotės už 18,6 mlrd. USD). Rusijos ginkluotės eksportas pastaraisiais metais nuolat auga, $1998 \mathrm{~m}$. jis sudare $2,2 \mathrm{mlrd}$. USD, o 2002 m. - 4,8 mlrd. USD 2 .

Palyginus su SSSR laikais, kai metinis eksportas siekè 14-20 mlrd. USD, šie duomenys neatrodo itin įspūdingi, tačiau būtina atkreipti dèmesį į tai, jog grynosios valiutinès pajamos už ginklų eksportą šiuo metu yra didesnès nei SSSR laikais. Taip yra todèl, kad daugiau nei $90 \%$ ginkluotės SSSR tiekè savo sajungininkėms socialistinès pagalbos forma (pavyzdžiui, kreditu, kuriu grąžinimo galimybès buvo itin miglotos).

Nagrinejjant Rusijos ginkluotès eksporto geografiją pastebėtina, jog didžioji dalis jo tenka besivystančioms valstybèms (daugiau nei $90 \%$ ). Dèl NATO standartų neatitikimo bei politinių priežasčiu eksportas ị Vakarų valstybes praktiškai nevyksta. Santykiškai nedidelis eksportas i Graikiją (apie 1 mlrd. USD 1997-2004 m. laikotarpiu), Kiprą (S-300 priešlèktuviniai kompleksai), Slovakiją, Bulgariją bei Vengriją (naikintuvų MIG-29 modernizacijos darbai) yra veikiau išimtys nei tendencija.

Svarbiausios Rusijos klientės - Indija bei Kinija: šioms valstybėms tenka apie $80 \%$ Rusijos ginkluotès eksporto.

Kasmet Kinijai Rusija pateikia ginkluotės už maždaug 2,3 mlrd. USD, o nuo 1992 m. Kinija nupirko ginkluotès už maždaug 15 mlrd. USD. Šiuo metu Kinijai teikiami naikintuvai SU-27, SU-30, priešlèktuviniai kompleksai S-300, karo laivai.

Rusijos prekyba su Kinija yra gana paradoksali. Kinijos Rusija nelaiko savo sajungininke, todèl į šią valstybę iki šiol draudžiama tiekti kai kuriuos pačios naujausios ginkluotės pavyzdžius (naujausi naikintuvų SU-30 modeliai, strateginiai bombonešiai ir t. t. ). $O$ ir tie naujausios ginkluotès pavyzdžiai dažnai yra tiekiami dirbtinai pabloginti.

Tačiau Kinija nelabai turi pasirinkimą, kadangi JAV ir ES dèl įvykių Tianenmenio aikšteje taiko Kinijai ginklų tiekimo embargą. Todèl 90 \% šios valstybės ginklų perkama iš Rusijos.

${ }^{1}$ Richard F. Grimmett, CRS Report for Congress. Conventional Arms Transfers to Developing Nations, 1997-2004, p. 3.

${ }^{2}$ Ten pat. 
Prekybos ginklais tendencijos su Kinija Rusijai nèra palankios. Artimiausiu metu ES, spaudžiama savo ginklu gamintoju, planuoja panaikinti ginklų eksporto embargą Kinijai. Taigi Rusijos ginkluotei teks rimtai konkuruoti su Prancūzijos, Švedijos ir Didžiosios Britanijos gaminiais.

$\mathrm{O}$ ir pačios Kinijos jau nebetenkina prekybos su Rusija sąlygos. Kinija pati yra stambus ginklų eksportuotojas (metinis eksportas svyruoja tarp 0,6-1,0 mlrd. USD per metus). Tuo pat metu Kinijos karo pramoné pagal technologini išsivystymą kol kas labai atsilieka nuo Rusijos bei Vakaru valstybių. Tačiau šis atotrūkis dèl didžiulių Kinijos Vyriausybès pastangų sparčiai mažèja. Kinija siekia, kad Rusija perduotu jai naujausiu ginkluotès rūšių gamybos licenzijas (iki šiol Rusija Kinijai tiekè tik pasenusios ginkluotės gamybos licenzijas bei sudètines dalis), ji jau nèra patenkinta vien importuotojos statusu.

Paskutiniai stambūs ginkluotės Kinijai tiekimo kontraktai buvo pasirašyti 2002-2003 m. Šiuo metu Kinija jau nebesuinteresuota naujų kontraktų šiuo metu tiekiamoms pozicijoms pasirašymu. Taip pat laikinai buvo užšaldytas kai kurių stambių jau pasirašytų kontraktų vykdymas (pavyzdžiui, vietoje planuotų 200 SU-27 naikintuvų gamybos komplektų Kinija nupirko tik 95, motyvuodama tuo, jog šis naikintuvas jau yra morališkai pasenęs). Vienintele išimtimi tapo neseniai pasirašytas kontraktas dèl IL-96 transporto léktuvų tiekimo už 1,5 mlrd. USD.

Tuo pat metu Rusija yra spaudžiama parduoti naujausią strateginę ginkluotę, tokią kaip strateginiai bombonešiai TU -22M3, naujausių modifikacijų naikintuvus SU-30 su paskutinės kartos radarais ir t. t. Tokios ginkluotės pardavimas susilaukia didelio JAV pasipriešinimo, kadangi ši ginkluote gali pakeisti jėgų balansą regione galimo konflikto dèl Taivanio akivaizdoje.

Žvelgiant iš pačios Rusijos saugumo interesu, vargu ar verta ginkluoti būsimą potencialų priešininką (kaip viena didžiausių saugumo grèsmių yra vertinamas Kinijos demografinis, o vèliau galbūt ir karinis spaudimas Sibire, be to, Kinija turi nemažai teritorinių pretenzijų Rusijai). Rusijos kariuomenė daug prasčiau aprūpinta rusiška šiuolaikine ginkluote nei Kinijos. O ir tai, jog Kinijai kol kas nėra tiekiami naujausi ginkluotės pavyzdžiai, nereiškia, jog jie yra pačiu Rusijos kariškių dispozicijoje.

Sprendžiant iš pastarojo meto įvykiu, Rusija nusileis Kinijos spaudimui ir pradès jai tiekti naujausią strateginę ginkluotę. Per $2005 \mathrm{~m}$. vasarą vykusius pirmuosius bendrus Rusijos ir Kinijos kariuomenių manevrus Kinijos kariškiams buvo demonstruojami naujausių Rusijos ginklų pranašumai. Akivaizdu, jog Rusijos Vyriausybè pasidave ginkluotès eksportuotojų spaudimui (ji ne kartą artikuliavo Rusijos spauda bei suinteresuoti ekspertai ${ }^{3}$ ) ir nusprendè, jog 2 mlrd. USD per metus pajamų netektis yra per daug rimta.

Kitas stambus Rusijos karinès technikos pirkejjas yra Indija. $2004 \mathrm{~m}$. į šią šalį eksportuota ginklų už 1,8 mlrd. USD ${ }^{4}$ Indijos rinkai būdingas gerokai aukš-

${ }^{3}$ ИНТЕРФАКС-АВН, Россия должна предлагать Китаю самые современные образцы вооружений эксперт, 20050906.

${ }_{4}^{4}$ „В борьбе за Индию российским оборонщикам нужна помощь Вашингтона“, STRANA.RU, http:// www.strana.ru/stories/02/02/01/2447/240463.html. 
tesnis konkurencijos lygis: čia Rusijai tenka aktyviai konkuruoti su JAV ir Vakarų Europos valstybėmis. Didžiausia konkurencija naikintuvu tiekimo srityje. Tačiau Rusijai 2004 m. pavyko pasirašyti itin stambų kontraktą (2,5 mlrd. USD) dèl lèktuvnešio „Admirolas Gorškovas“ pardavimo. Kartu su lèktuvnešiu Rusija taip pat teiks naikintuvus MIG-29 bei malūnsparnius KA.

Rusijos perspektyvos Indijos rinkoje, ekspertų nuomone, miglotos, kadangi Indijos kariuomenè itin reikli tiekiamos produkcijos kokybei. Vis dèlto Rusija imasi aktyvių veiksmų šioje rinkoje (pavyzdžiui, bendrų karinių mokymu, deklaracijų apie užsienio politikos prioritetų bendrumą ir t. t. ). Pastebètina, kad, skirtingai nuo Kinijos, Rusija aktyviai bendradarbiauja su Indija kuriant bendrą ginkluotę. Tokios sėkmingos kooperacijos pavyzdžiu yra bendra Rusijos - Indijos sukurta raketa „Bramos“, kuria bus ginkluojamos tiek Indijos, tiek Rusijos kariuomenès ${ }^{5}$. Taip pat Indija aktyviai dalyvauja bendrame penktos kartos naikintuvo kūrimo projekte, kurį Rusijoje vykdo koncernas "Sukhoi“.

Rusijai taip pat itin perspektyvios Pietryčių Azijos bei Lotynų Amerikos rinkos, tačiau čia kol kas nepasiekiama itin didelių laimëjimų. Santykiškai nedideli Malaizijos, Vietnamo bei kitu valstybių užsakymai vargu ar leis ateityje kompensuoti Indijos ar Kinijos rinkų praradimą.

Neišsipildè Rusijos analitikų lūkesčiai, jog dèl JAV invazijos ị Iraką padidès Rusijos ginkluotès paklausa Artimujų Rytų regione. Rusijos ginklų tiekimo kontraktai šiame regione išliko itin riboti. O Rusijos planai tiekti Sirijai naujausias raketas „Iskander" susilaukẻ didžiulio Izraelio bei JAV pasipriešinimo ir kontraktą teko atšaukti ${ }^{6}$.

Analizuojant Rusijos eksportą pagal ginkluotès rūšis pastebėtina, kad absoliučiai didžiajją dalį eksporto ( $70-75 \%$ ) sudaro aviacijos pramonės produkcija, visu pirma naikintuvai „,SU-27“ bei „SU-30“. Paklausą pasaulinèje rinkoje turi malūnsparniai „MI", naikintuvai „MIG-29", kariniai laivai bei priešraketinès sistemos. Dèl stambiu kontraktų su Kinija bei Indija aviacijos srityje užbaigimo artimiausiu metu galima tikètis, kad vis didesnę svarbą eksportuojant Rusijos ginkluotę turès kariniai laivai bei priešraketinės gynybos kompleksai.

Dabartinį itin sẻkmingą Rusijos ginkluotès eksporto didẻjimą galima paaiškinti $2000 \mathrm{~m}$. ịvykdyta administracine reforma ginkluotės eksporto srityje. Vietoje tarpusavyje dažnai konkuravusių ir neskaidriomis operacijomis pasižymëjusių valstybinių imonių „,Promeksport" , ,Rossiskije technologii“ ir ",Rosvooruženije “ buvo sukurtas bendras valstybinis ginklu prekybos tarpininkas „Rosoboronksport". Šiai valstybinei įmonei suteiktos išskirtinès teisès prekiauti didžiąja dalimi Rusijos ginkluotės. Be to, anksčiau ginklų eksportas buvo kuruojamas Vyriausybès, o „Rosoboroneksport" per specialiai tuo tikslu sukurtą Karinio Techninio Bendradarbiavimo Komitetą yra pavaldus Rusijos Prezidentui (tai tapo dar vienu „valdžios vertikalès“ pavyzdžiu).

${ }^{5}$ „Индийские Су-30 вооружат сверхзвуковой крылатой ракетой“, LENTA.RU ,http:lenta.ru/world / 2005/02/11/bramos /

${ }^{6}$ РОСБАЛТ, Российский ВПК: последний бросок на юг?, 20050512. 
Šiuo metu „Rosoboroneskport“ kontroliuoja 86 \% Rusijos ginklu prekybos. Griežta ginklų eksporto sistema leido išvengti Rusijos ginklu gamintojų tarpusavio konkurencijos užsienio rinkose, pagerino veiksmų šioje srityje koordinaciją. Darbas per „,Rosonoroneksportą“ GPK įmonėms turi tiek privalumu, tiek trūkumų: iš vienos pusės tai apsimoka, kadangi ši struktūra turi gerai išvystytą realizacijos tinklą bei užmegztus kontaktus su potencialiais ginkluotės pirkejjais. Taip pat svarbu, jog valstybinis tarpininkas užtikrina, kad įmonės gamintojos kokybiškai ir laikų įvykdytų kontraktų sąlygas, esant reikalui suteikia finansinę paramą. Tačiau už tai įmonèms tenka mokèti nemažus komisinius. Tenka konstatuoti, kad pačios „,Rosoboroneksport“" veikla užsienio rinkose nèra visiškai skaidri. Parduodant ginkluotę besivystančioms šalims dažnai naudojamasi vietiniais tarpininkais, turinčiais artimų kontaktų su atsakingais už ginkluotės įsigijimą pareigūnais. Plačiai nuskambèjo skandalas Bangladeše, kai šiai šaliai naikintuvai „MIG-29“ buvo parduoti už $17 \mathrm{mln}$. USD, nors Birmai analogiški naikintuvai buvo pasiūlyti už $10 \mathrm{mln}$. USD .

Dèl galimybės savarankiškai užsiimti ginkluotės eksportu nuolat vyksta aktyvi interesu kova. Šiuo metu dar 4 Rusijos ginklų gamintojai (tarp ju RAC „MIG", NPO „Mašinostroenije“) turi teisę eksportuoti savo produkciją tiesiogiai, tačiau norinčių taip dirbti įmonių yra kur kas daugiau, kadangi nenorima dalyntis pelnu bei klausyti valstybinio tarpininko diktato, kaip dirbti užsienio rinkose. Visdèlto stambiu kontraktų su Indija bei Kinija atveju, kai ginkluotès realizacijai būtina valstybės politinè parama, net nepriklausomi eksportuotojai realizuoja savo produkciją per „Rosoboroneksporto“ struktūrą (tai, pavyzdžiui, nutiko „MIG-29“ eksporto Indijos jūrų pajègoms atveju).

RF Gynybos ministerija 2004 m. pasiekè, kad jai būtų leista savarankiškai pardavinèti pasenusią ginkluotę bei karo techniką, kuri yra nurašoma iš Rusijos armijos sandèlių.

Taip pat nuo $2005 \mathrm{~m}$. rugsëjo kai kurioms Rusijos įmonėms buvo leista tiesiogiai tiekti karinès technikos detales, gerokai palengvino tokio eksporto tvarką (anksčiau sprendimus šiuo klausimu priimdavo Karinio Techninio Bendradarbiavimo Komitetas). Tai leidžia Rusijos ginkluotės eksportui ištaisyti itin svarbų savo trūkumą - vẻluojantị detalių ir mazgų tiekimą bei lètą techninị patiektos karinès technikos aptarnavimą (šioje srityje Rusija itin nusileidžia savo konkurentams iš Vakaru).

„Rosoboroneksporto“ vadovo S. Čemezovo nuomone, Rusijos ginkluotės eksportas šiuo metu yra maksimaliai išnaudojamas pagal esamą gynybos pramonès situaciją ${ }^{8}$. Tą partvirtina ir tai, jog pastaruosius dvejus metus jo apimtys praktiškai neauga. Sprendžiant pagal oficialių asmenu pasisakymus, gali atrodyti, jog Rusijos ginkluotės eksporto perspektyvos yra itin šviesios, atrandamos vis naujos rinkos (Tailandas, Brazilija, Venesuela, Indonezija, Malaizija ir t. t. ).

\footnotetext{
7 ,Бангладеш пересматривает сделку по приобретению МиГ-29“, http:/ /www.avias.com/news/ 2001/10/24/18326.html

8,„Российское оружие перестанет бить в цель“, UTRO.RU, http://www.utro.ru/articles/2005/ $09 / 28 / 481000$. shtml.
} 
Tuo pat metu skelbiama apie tai, jog iki 2007-2008 m. turima pasirašytu kontraktų suma sudaro apie $12 \mathrm{mlrd}$. USD. Strategiju analizės centro ekspertai irgi optimistiški: Rusija gali tikètis iki 2010 m. parduoti apie 220 naikintuvu, itin didelè povandeninu laivu, fregatų bei priešraketinių kompleksu paklausa ${ }^{9}$. Koncernas "Sukhoi“ skelbia, jog kasmet planuoja eksportuoti naikintuvų už 1,5 mlrd. USD, atsarginių dalių jiems už $800 \mathrm{mln}$. USD. Ambicingi ir kitų Rusijos eksportuotojų planai ${ }^{10}: 2006 \mathrm{~m}$. sausį pasirode pranešimai apie su Alžyru pasirašytą ginkluotės tiekimo kontraktą, kurio bendra suma 4 mlrd. USD.

Tačiau dauguma perspektyvų vis dar lieka tik deklaruojamos ir planuojamos ir jau 2007-2008 m. Rusija gali susidurti su rimtomis problemomis eksportuodama savo karinę techniką, visų pirma karinius naikintuvus. Kaip jau buvo minėta, itin neaiškios perspektyvos yra didžiausiu pirkèjų - Kinijos bei Indijos rinkose. O ypač sunkūs laikai Rusijos aviacijos produkcijai prasidės, kai po $2010 \mathrm{~m}$. JAV kariuomenè pradės masiškai keisti pasenusius naikintuvus naujais penktosios kartos (F-35 bei F-22). Tada pasaulio rinkoms bus pasiūlytas didelis kiekis naudotu ketvirtosios kartos naikintuvu F-15, F-16 bei F/A-18 itin palankiomis kainomis. Šie ketvirtosios kartos naudoti naikintuvai tiesiogiai konkuruos su nauja Rusijos gamybos produkcija, kuri šiuo atveju nebeteks vieno pagrindiniu savo kozirių - žemesnių kainų.

Pagrindinė Rusijos ginkluotès eksporto problema ta, jog ji pamažu netenka dviejų pagrindinių pranašumų -šiuolaikinių technologinių standartų atitikimo bei žemų kainų. Vieša paslaptis, jog beveik visa Rusijos karinio eksporto produkcija buvo sukurta dar SSSR laikais, Rusijos gynybos pramonè tesugebëjo pasiūlyti modifikuotas kai kurių ginklų versijas (tokias kaip, pavyzdžiui, naikintuvo „MIG-29“ lèktuvnešiams skirtą modifikaciją). Būtent nuo galimybių (o ir noru) pasiūlyti eksporto rinkoms naujos technologinės kartos ginkluotę (tokią kaip, pavyzdžiui, penktosios kartos naikintuvas, priešraketinis kompleksas S-400 „Triumf“) priklausys Rusijos ginkluotès eksporto ateitis.

Taip pat itin perspektyvi Rusijai yra dar SSSR laikais pateiktos ginkluotės, kuri šiuo metu naudojama daugelyje pasaulio kariuomeniu, modernizacija. Nors ši rinka potencialiai vertinama 100 mlrd.USD, kol kas Rusijai ne itin joje sekasi ${ }^{11}$. Tai susiję tiek su daugelio potencialiu klientų nemokumu, tiek su tuo, jog modernizacijos rinkoje aktyviai bando veikti Ukraina, Izraelis, Lenkija bei kitos valstybès.

Nepavykus išlaikyti esamų ir išnaudoti potencialių nišų Rusijos ginkluotės eksportas gali susiaurèti iki anksčiau parduotos karinès technikos aprūpinimo atsarginėmis dalimis bei ginklų tiekimo valstybėms, kurios neturès galimybiu pirkti ginklų kur nors kitur, išskyrus Rusiją, o tai taps rimta problema visam Rusijos gynybos pramonės išlikimui.

\footnotetext{
${ }^{9}$ Макиенко К., „Насыщение рынка. Российский экспорт боевых самолетов: золотой век позади?“, ЦЕНТР ACT, http:/ / www.cast.ru/comments/?id=196 .

10 Ten pat.

${ }^{11}$ Иванов Владимир, ,Продавать оружие можно, но по частям“, Независимая газета, 20050903.
} 


\section{Pastarojo meto Rusijos ekonomikos raidos tendencijos}

Rusijos gynybos pramonès komplekso situaciją vargu ar galima vertinti neatsižvelgiant i pastarojo meto visos Rusijos ekonomikos raidą. $\mathrm{O} j \mathrm{ji}$, nepaisant išorinės gerovès iliuzijos, yra itin prieštaringa.

Po 1998 m. finansinès krizès Rusijos ekonomika jau šešeri metai iš eilès yra nepaliaujamo augimo fazèje. Tą iš dalies sąlygojo pervertintos nacionalinès valiutos - rublio devalvacija, padariusi Rusijos gamintoju produkciją kur kas patrauklesnę vidaus ir užsienio rinkose.

Tačiau svarbiausiu ir esminiu atsigavimo faktoriumi tapo itin palanki kainų konjunktūra pasaulinėse energetinių ir kitų žaliavų rinkose. Antai 1998 m., prieš pat krizę, Rusijos eksportuojamos naftos kaina buvo pasiekusi 9 USD už barelį lygi, tačiau nuo to laiko ji praktiškai visą laiką auga ir iki $2005 \mathrm{~m}$. rudens pasiekè 50-60 USD už bareli.

Augančios naftos kainos itin teigiamai veikia makroekonominius rodiklius: Rusijos BVP kasmet auga 5,3-8\%. (2005 m. augimas sudare 6,3\%). Teigiamas užsienio prekybos saldo vien per devynis $2005 \mathrm{~m}$. mènesius sudare 92,8 mlrd. USD, o Centrinio banko valiutos atsargos išaugo 35,4 mlrd.USD ${ }^{12}$. Rusija pirmą kartą nuo SSSR žlugimo laikų tiesiog maudosi ",naftos doleriuose“.

Tačiau, nepaisant tokių didžiulių pajamu, tikroji Rusijos ekonomikos situacija tik blogèja. Geri makroekonominiai rodikliai valstybëje sudaro gerovės iliuziją ir neskatina vykdyti būtinų struktūrinių reformų.

Rusijoje aiškiai pastebima vadinamoji „olandiška liga“, kai žaliavų eksporto sektorius praktiškai išskirtinai akumuliuoja savyje didžiają dalį valstybės lëšų. Pelnas šioje srityje yra nepalyginti didesnis nei daugumoje kitų ekonomikos sričiu.

Didžioji dalis Rusijos pramonės yra itin silpnai konkurencinga tiek vidaus, tiek tuo labiau pasaulinėje rinkoje, todèl augančios valstybės pajamos visų pirma skatina užsienio gamintojų prekių importą. Rusijos pramonę žlugdo nesugebejjimas prisitaikyti prie naujų ekonominių realiju, aukštas santykinis rublio kursas, nuolatinis gamybos išlaidų augimas dèl augančių i̇monių - monopolisčiu ( „,GAZPROM“, RAO EES, „Rusijos geležinkeliai“ ir t. t. ) paslaugu ịkainių bei daugybė kitų faktorių. Todèl nuo $1998 \mathrm{~m}$. stebėtą augimą (vien 2000$2004 \mathrm{~m}$. pramonès produkcijos apimtis išaugo $40 \%{ }^{13}$ ) $2005 \mathrm{~m}$. jau praktiškai pakeitė stagnacija. Vertinant statistiką reiktų pastebėti, kad į pramonės gamybos augimą yra įskaičiuojama ir naftos gavyba ir perdirbimas.

Visa tai tik dar labiau didina Rusijos priklausomybę nuo situacijos pasaulinėse žaliavų rinkose. Tai pamažu verčia Rusiją pagal ekonomikos struktūrą panéšèti i "trečiojo pasaulio" valstybes ir daro jos ambicijas tapti viena iš

\footnotetext{
${ }_{12}$ Министерство экономического развития и торговли РФ, О текущей ситуации в экономике Российской Федерации в январе-сентябре 2005 г. и оценках до конца года, http:/ /economy.gov.ru, 20051101. ${ }^{13}$ Федеральная служба государственной статистики РФ, Основные показатели промышленности, http:/ /www.gks.ru.
} 
visaverčiu pasaulio ekonomikos veikëjų vis mažiau realiomis. Net galimybės ateityje eksportuoti stabiliai didelį naftos kiekį nèra aiškios dèl vis mažẻjančiu investicijų i naujų verslovių žvalgybą.

Tačiau, matyt, svarbiausia struktūrinè problema yra ta, jog Rusija pamažu baigia "pravalgyti“ iš SSSR paveldètą materialinių investicijų bagažą. Nuo 1992 m. į infrastruktūrą, pramonę ir t. t. buvo praktiškai neinvestuojama (daugiausia dèl lèšų stokos). Todèl griūva namai, vis dažniau vyksta technogeninés katastrofos (tokios kaip elektros avarija Maskvoje, palikusi be šviesos $4 \mathrm{mln}$. gyventoju $\left.{ }^{14}\right)$, ištisi regionai žiemą lieka be šildymo, ir šios tendencijos kas metai vis stiprëja ir vis plačiau yra šnekama apie „2007 m. krizę“, kai masiškai pradès griūti šalies infrastruktūra.

Esant tokioms aplinkybėms tiek Vyriausybė, tiek ekspertai sutaria dèl vieno dalyko - taip toliau tęstis negali. Tačiau sutarimo, kaip spręsti egzistuojančias problemas, nèra.

Iš pirmo žvilgsnio sunku paaiškinti, kodèl tuo pat metu daromi liberalūs žingsniai (kaip stojimas ị PPO, socialinių lengvatų monetarizacija) ir paraleliai vykdomas turto perskirstymas, konsoliduojant vis didesnius finansinius srautus valstybės rankose. Šiuolaikinès Rusijos ekonominè politika yra itin nevienalytė, iš dalies primenanti žymią A. Krylovo pasakèčią apie gulbę, véžį ir lydeką, tempiančius vežimą i skirtingas puses, o jis kaip stovejo vietoje, taip ir stovi.

Priežastis yra ta, kad Rusijos valdančiuose sluoksniuose visą laiką vyksta kova tarp dviejų požiūrių į ekonominę politiką: liberalaus ir dirižistinio. (Šis skirstymas ir terminai šiame straipsnyje yra pasiskolinti iš Rusijos ekonomisto M. Zadornovo ${ }^{15}$.) Dabartinëje Rusijos Vyriausybëje aiškiai galime išskirti abieju kursų šalininkus. Liberalai - ekonominio bloko ministrai - G. Grefas bei I. Kudrinas. Dirižistai - Premjeras M. Fradkovas, M. Alešinas, V. Christenko. Iš tikruju naujoji interesų konfigūracija yra žinomas amžino konflikto tarp liberalių reformų šalininkų ir priešininkų Rusijos ekonominëje politikoje, kurị galima pastebèti nuo pat 1992 m., įsikūnijimas, o šios personalijos - kur kas platesnès diskusijos, nuolat vykstančios Rusijos ekonomikoje, dalis.

Šiandieniniai liberalai jau nèra tie vienpusiški neoliberaliu „Vašingtono konsensuso" idèjų skleidejjai Rusijai, kokiais buvo E. Gaidaras ar A. Čiubaisas. Tačiau juos taip pat skiria tikejimas laisvos rinkos galia. Ju nuomone, Rusijos ekonomikai nesiseka, nes ji nèra pakankamai liberali, egzistuojantys biurokratiniai trukdžiai neleidžia privačiam verslui efektyviai veikti. Tuo pat metu valstybiné nuosavybė jau ne kartą įrodè savo neefektyvumą.

Dirižistai pagrindinemis Rusijos ekonominių problemų kaltininkėmis įvardija pagal Vakaru scenarijus vykdytas neoliberalias drastiškas reformas, visiškai netinkamas Rusijai. Jiems šiuolaikinis pasaulis yra itin nedraugiška vieta, kur išsivysčiusios Vakarų valstybės su JAV priešakyje eksploatuoja likusi pasauli. Rusijai yra paskirta vieta tarp eksploatuojamų valstybiu, kurių funkcija - tiekti žaliavas ${ }^{16}$. Liberalios reformos kaip tik ir sudaro sąlygas Vakarų kapi-

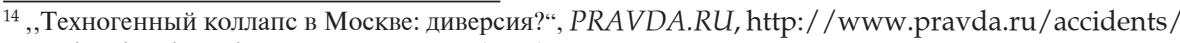
2005/10/72/203/19923_KOLLAPS.html .

${ }^{15}$ Михаил Задорнов, ,ЭЭономисты” против “дирижистов“, Московские новости, 20050311.

${ }^{16}$ И. Панарин, ,,Время собирать камни...“, Экономика и жизнь 16, 20030407. 
talui vis labiau ịsigalèti Rusijos rinkoje, tuo pat metu Vakarų korporacijos visiškai nesuinteresuotos Rusijos ekonomikos augimu: joms kur kas svarbiau užimti rinką bei sunaikinti konkurentus - per ilgus liberalių reformų vargus dar išlikusią Rusijos pramonę. Dirižistai kaltina liberalus per dideliu dèmesiu makroekonominiams rodikliams už jų nematant ekonominių procesų, vykstančių Rusijos ekonomikoje.

Tiek dirižistai, tiek liberalai sutaria, jog Rusijai jokiu būdu negalima tenkintis žaliavų tiekëjos statusu, nes tokia ekonomika neužtikrins aukšto gyvenimo lygio Rusijos piliečiams ir neleis spręsti kitų ekonominių uždavinių. Tuo pat metu šiuolaikiniame ekonominès globalizacijos pasaulyje valstybės vieta hierarchijoje priklauso nuo to, kaip gerai išvystytas jos aukštujų technologijų sektorius.

Dirižistų nuomone, Rusijai vienintelis šansas sukurti konkurencingą aukštuju technologijų sektoriu - pasinaudoti Gynybos Pramonės Kompleksu (GPK). Gynybos pramonè dar sovietiniais laikais buvo vienintelis sektorius, kur koncentravosi visos SSSR aukštosios technologijos.

Dirižistinès politikos šalininkai kalba apie būtinybę gynybos pramonès sektoriaus reformai panaudoti Stabilizacinio fondo, kuriame jau šiuo metu yra sukaupta 34 mlrd., o per artimiausius metus kasmet planuoja sukaupti po 4550 mlrd. USD ${ }^{17}$, lèšas. Stabilizacinio fondo lëšu panaudojimo būtinybẻ yra vienas labiausiai diskutuotinu klausimų šiandienineje Rusijos politinëje dienotvarkèje. Iš tikruju gana paradoksaliai atrodo situacija, kai Rusijos ekonomikoje kaupiasi struktūrinės problemos, o tokios nemažos léšos (kurios, pavyzdžiui, jau $2005 \mathrm{~m}$. spalị buvo lygios dviem metiniams gynybos biudžetams) saugomos ,juodai dienai“" (investuotos į Vakarų valstybių iždo obligacijas). Investavus valstybines lèšas būtu galima itin paspartinti šiuo metu praktiškai užstrigusius mokslinius tyrimus, kurti naują pasaulinėje rinkoje konkurencingą ginkluotę, o kariniame sektoriuje sukurtos technologijos taptų visos Rusijos ekonomikos augimo lokomotyvu.

Liberalai itin neigiamai vertina valstybinių lěšų naudojimą gynybos pramonei remti, kaip ir ekonomikai remti apskritai. Jų nuomone, esant dabartinei neefektyviai ekonomikos struktūrai valstybės skiriamos lëšos bus paprasčiausiai „pravalgytos“, o dar blogiau - pasisavintos korumpuotos šių lèšu skirstytojų ir naudotojų sistemos. Todèl vietoje ekonominio efekto bus sulaukta infliacijos augimo.

Nors Rusijoje GPK yra praktiškai vienintele ekonomikos šaka, kurioje išliko technologinis potencialas, tačiau mažai tikètina, kad jo pagalba Rusija galètų sukurti diversifikuotą, aukštomis technologijomis paremtą ekonomiką. Šiuo metu gynybos pramonè užtikrina $75 \%$ Rusijos mokslinès produkcijos, 100 $\%$ aviacinès, kosminès, elektroninès ir optinès technikos, bei 70-90\% likusios aukštujų technologijų produkcijos gamybos ${ }^{18}$.

Rusija sparčiai praranda turimą mokslinį potencialą, drauge prarasdama galimybes naudotis turimomis technologijomis. Šiuo metu Rusija kariniu

\footnotetext{
${ }_{17}$ РОСБАЛТ, Путин утвердил цену отсечения на нефть для Стабфонда, 20051013

18 „Оборонно-промышленный комплекс: кризис или выздоровление“, Независимое военное обозрение, 20051028 .
} 
naikintuvu gamybos srityje jau 5-15 m. atsilieka nuo JAV. Itin ryškus technologinis atsilikimas informaciniu technologiju bei elektronikos srityje, o tai labai apsunkins naujos šiuolaikinės aukšto tikslumo ginkluotės gamybą ${ }^{19}$.

Tačiau technologijos dar nereiškia ekonominio augimo. Daugums sukauptų technologijų yra išimtinai karinio pobūdžio ir skirtos ginkluotės gamybai. Nuo SSSR laikų GPK sektoriui nèra būdingas sugebẻjimas efektyviai naudoti karines technologijas civilinés produkcijos gamybai. Tai rodo ir itin menkas Rusijos GPK įmonių produkcijos konkurencingumas vidaus bei užsienio rinkose. Nepaisant to, jog Rusijos energetinės kompanijos nemažai investuoja i reikiamą įrangą, didžioji dalis jos yra importuojama, kadangi šalies GPK beveik negali pasiūlyti konkurencingų analogų.

Nepaisant to, jog civilinės produkcijos gamyba sudaro $43 \%$ visos produkcijos, 10 stambiausių Rusijos GPK įmonių didžią̧ą dalį lěšų uždirba iš karinių užsakymu, civilinės gamybos apimtis jose sudaro tarp 3 ir $20 \%$. Reta išimtimi čia yra tankų T-90C gamintojas „Uralvagonzavod“, kuris „,Rusijos geležinkelių" užsakymu gamina vagonus ir geležinkelio cisternas (civilinės produkcijos dalis $2004 \mathrm{~m}$. sudare $84,2 \%)^{20}$.

Stambios naikintuvų gamintojos „Irkut" bei „Sukhoi“" kuria civilinių lèktuvų modelius, kurie ateityje konkuruos civilinės produkcijos rinkoje. Antai „Sukhoi“" planuoja, kad civilinio lèktuvo RRJ (Russian Regional Jet) pardavimai gali sudaryti 1 mlrd. USD per metus.

Tačiau tuo atveju, jei investuojamos į GPK lèšos tik didins gynybos pramonès galimybes kurti naują ginkluotę, turint omenyje itin mažą eksporto apimti, tai taps ne ekonomikos lokomotyvu, bet papildoma našta Rusijos biudžetui, naudojančiam kol kas neribotomis atrodančias pajamas iš energijos ištekliu eksporto.

\section{Karinès pramonès dabartis}

Vertinant vien oficialią statistika, pastaraisiais metais situacija GPK, lygiai kaip ir visoje Rusijos ekonomikoje, sparčiai taisosi. Štai per 2000-2004 m. GPK gamyba išaugo $70 \%$. Vien per $2004 \mathrm{~m}$. karinès produkcijos gamyba išaugo $9,8 \%$ iki 10,1 mlrd. USD, o civilinès - 12,9 \% iki 7,6 mlrd. USD. Tačiau šis augimas slepia po savimi ịsisenejusias komplekso problemas.

Rusijos Gynybos Pramonės Kompleksas, tiesioginis SSSR karinès pramonès komplekso paveldètojas, gavo $70 \%$ sugriuvusios milžinės palikimo šioje srityje. Reikia pabrèžti, kad būtent SSSR GPK specifika ir lėmė dabartinę itin sudètingą šios šakos būklę.

SSSR GPK buvo adaptuotas Šaltojo karo realijoms ir jam buvo būdingas vadinamasis mobilizacinis apgulties modelis. Tai suponavo itin dideles išlai-

${ }^{19}$ Коптюбенко Д., ,Россию защитят 14 новых танков“, РБК-Дейли, http:/ / www.rbcdaily.ru/news / market/index.shtml?2003/12/25/49822 20051201.

${ }^{20}$ Никольский А., ,,ВПК на голодном пайке. Деньги государства в прошлом году не дошли до оборонки“, Ведомости, 20050609. 
das ir dėmeși šiai sričiai. JAV šaltinių duomenimis, 1987 m. ginklų ir karinès technikos gamyba (ịskaitant eksportą, mokslinius tyrimus ir valstybès paramą) $2000 \mathrm{~m}$. kainomis SSSR sudare $90 \mathrm{mlrd}$. USD. Dar apie $90 \mathrm{mlrd}$. sudare civilinès produkcijos gamyba GPK. Šioje pramonès šakoje dirbo apie $11,5 \mathrm{mln}$. žmonių ${ }^{21}$. Neproporcingai didelès išlaidos ir tapo viena svarbių SSSR ekonomikos kolapso priežasčių. Praktiškai visa SSSR ekonomika dirbo tik tam, kad išlaikytų karinio komplekso monstrą. Akivaizdu, kad po SSSR žlugimo kardinaliai kritus valstybẻs užsakymų ir eksporto apimčiai GPK įmonès atsidūrè ties išgyvenimo riba. GPK tiesiog buvo ir yra per didelis šiuolaikinei Rusijos ekonomikai.

Mobilizacinis ekonomikos pobūdis lèmè, jog gynybos pramonès įmonès privalëjo visą laiką palaikyti didelius atsarginius gamybos išteklius, kad ilgo ir sekinančio karo sąlygomis galėtų dideliu kiekiu gaminti reikalingą kariuomenei produkciją. Be to, skirtingai nuo Vakarų valstybių gynybos pramonės įmonių, kurios užsako komplektuojančias dalis iš daugelio šaltiniu, SSSR įmonès iš esmès buvo izoliuotas kompleksas, gaminantis praktiškai viska, kas reikalinga galutiniam gaminiui, pradedant varžtais ir baigiant varikliais ir t. t. Keisčiausia, kad net ir po $1992 \mathrm{~m}$. Rusijos GPK įmonès privalëjo išlaikyti iš esmès tas pačias mobilizacines gamybos pajègas kaip ir SSSR laikais, nepaisant to, jog valstybès finansavimas šioms išlaidoms dramatiškai krito ${ }^{22}$. Tai vertè ir taip sunkioje padètyje esančias įmones užsikrauti dar didesnę finansinę naštą, kurios niekaip negali atsikratyti.

Mobilizacinė ekonomika tapo ir vienos didžiausių dabartinio GPK rykščių - vidinès konkurencijos - priežastimi. SSSR laikais buvo priimta dubliuoti kiekvienos strateginės ginkluotės gamybą. Todèl šiuo metu, pavyzdžiui, naikintuvus SU-27 gamina Irkutsko (APO „IRKUT"), Novosibirsko ir Komsomolsko prie Amūro gamyklos (AKH „Sukhoi“), malūnsparnius MI-Kazanės, Maskvos ir UlanUde gamyklos, priešraketines sistemas S-300 - „Almaz Antei“ ir „Oboronitelnyje sistemy" (beje, šios įmonės atskirai viena nuo kitos sukūrè konkuruojančius tarpusavyje naujos kartos priešraketinius kompleksus) ${ }^{23}$, ir taip praktiškai bet kurioje gynybos pramonės šakoje. SSSR laikais dubliavimas turëjo racionalią logiką, kadangi visoms įmonèms centralizuotai buvo paskirstomas pakankamas valstybės užsakymas, o šiuolaikinejje Rusijoje jis virsta konkurencija dèl valstybès užsakymų ir eksporto kontraktų. Dažnai ši konkurencija pasireiškia net pasaulineje rinkoje, kai dèl to paties kontrakto konkuruoja „,MIG“ ir „SU“ naikintuvai.

Dar viena itin rimta problema, paveldeta iš SSSR laiku, - neefektyvus imonių valdymas. İmonės buvo ịpratusios veikti „,šiltnamio sąlygomis“, naudodamosi tuo, jog GPK buvo šalies ekonomikos prioritetas. Todèl esant naujoms ūkio sąlygoms daugelio jų vadovai, net ir drastiškai sumažejus finansavimui, vis dar tikëjosi, kad situacija pasitaisys, o visas problemas išspręs vèl padidèsiantis valstybės finansavimas.

\footnotetext{
${ }^{21}$ В. В. Карачаровский, „Российский высокотехнологичный промышленный комплекс: политикоэкономические императивы и безопасность развития“, МИР РОССИИ, http://www.socio.ru/wr/ 2-01/Karacharovsky.htm.

${ }^{22}$ Шлыков В., ,,Военная немощь“, Еженедельный журнал 45, 20021119.

${ }^{23}$ Sanchez -Andres A., "Arms Export and restructuring in the Russian Defence Industry", Europe - Asia Studies,56(5), 200407.
} 
SSSR GPK buvo būdinga tai, jog čia ekonominis efektyvumas buvo aukojamas dèl nacionalinio saugumo prioritetų. Svarbiausia - pagaminti, o kiek tai kainuos, nèra labai svarbu. Naujosiomis rinkos ekonomikos sąlygomis tokia logika jau iš principo tapo nebetinkama. Rusijos ekonomika (kuri per 19921998 m. prarado daugiau nei 60 \% BVP) negalejjo sau leisti tokios naštos.

Oficialiais Rusijos Pramonès ir Energetikos ministerijos registro duomenimis, Gynybos Pramonès Kompleksas šiuo metu jungia 1276 įmonių ir mokslinio tyrimo centru, kuriuose dirba apie $2 \mathrm{mln}$. žmonių ${ }^{24}$. Šių įmonių skaičius nuolat mažėja: dar $2001 \mathrm{~m}$. jų buvo 1700. Nepaisant to, jog, Rusijos oficialiu asmenu žodžiais, gamyba iki $2000 \mathrm{~m}$. krito 3-5 kartus, iš tikruju ji krito 20-30 kartu, kadangi paprastai yra lyginama su jau itin blogais gynybos pramonei 1992 m. Dideles problemas gynybos pramonei sukèlè ne tik visiškas jos struktūros naujų rinkos salygų neatitikimas ir bendra Rusijos ekonomikos degradacija, itin neigiamą įtaką turëjo ir nuolatiniai Rusijos valstybès didžiuliai įsiskolinimai už patiektą produkciją. Atskirais metais šių įsiskolinimų sumos viršydavo metinio valstybès karinio užsakymo dydį ${ }^{25}$.

Todèl didelẻ dalis įmoniu, oficialiai įeinančiu i GPK, lèšas, reikalingas išgyvenimui, užsidirba gamindamos civilinę produkciją, nuomodamos patalpas ir t. t. Akivaizdu, kad veikdamos tokiu režimu jos pamažu praranda galimybes ateityje kurti bei gaminti aukštos technologijos produkciją. Šiuolaikinis Rusijos GPK iš kažkada harmoningai veikusio SSSR gamybos komplekso, susieto plačiais kooperaciniais ryšiais, tapo atskirų įmonių ir mokslinių tyrimo centrų kovos dèl išgyvenimo arena.

Pagrindinę savo problemų priežastį Rusijos Gynybos Pramonės atstovai mato tą, jog valstybės ginklu įsigijimas yra nepakankamas. $2001 \mathrm{~m}$. patvirtintinta „Federalinè ginkluotès programa 2001-2010 m.“ šiuo metu yra svarbiausias dokumentas, nustatantis ginkluotè įsigijimo strategines kryptis. Šiame dokumente akcentuojama, jog Rusijos kariuomené neplanuoja dideliu ginkluotés ịsigijimų iki 2008-2010 m. Buvo numatyta, jog nauja ginkluote iki šio laiko bus issigyjama tik vienetiniais egzemplioriais. Siuo metu didžiausias akcentas yra skiriamas moksliniams tiriamiesiems darbams naujos ginkluotès kūrimo srityje. Čia pirmiausiai vertètų išskirti penktosios kartos naikintuvą, naujos kartos povandeninius laivus bei priešraketinę sistemą S-400.

Tokia ginkluotès įsigijimo tvarka faktiškai nurodo Rusijos ginklų gamintojams, kad, kol bus nepradèti masiniai ginkluotès pirkimai, jie turi išgyventi iš eksporto kontraktu bei civilinės produkcijos gamybos. Vakaruose ginklu gamintojams eksportas paprastai tèra papildomo pelno šaltinis ir pagrindines lěšas jie užsidirba iš valstybės karinių pirkimu, o Rusijos GPK lyderiams galimybès eksportuoti yra gyvenimo arba mirties klausimas. Šiuo metu eksportas sudaro $60 \%$ visos GPK karinės produkcijos, tačiau beveik visų šios pramonės lyderiu (tokių kaip ",Sukhoi“", ,MIG“, ,Almaz-Antei“", ,Admiralteiskije verfi“, „Irkut") apyvartoje pajamos iš eksporto sudaro 80-90 \% ${ }^{26}$. Rusijos GPK šiuo

${ }^{24}$ Гольц А., ,„Сизифов комплекс“, Еженедельный журнал 45, 20021119.

25 Sanchez -Andres A., "Arms Export and restructuring in the Russian Defence Industry“", Europe - Asia Studies, 56(5), 200407

${ }^{26}$ Никольский А., ,,ВПК на голодном пайке. Деньги государства в прошлом году не дошли до оборонки“, Ведомости, 20050609. 
metu vienos ar kitos įmonès finansinę būklę bei ateities perspektyvas pirmiausiai ir lemia tai, ar ji gauna pajamų iš eksporto.

Gynybos pramonè susiduria su iš pirmo žvilgsnio paradoksalia situacija: dèl mažo valstybès karinių priemonių įsigijimo išgyvenimui būtina eksportuoti, tačiau eksporto galimybès dèl to paties valstybinio užsakymo nebuvimo laipsniškai mažejja.

Tai ypač pasakytina apie kainų konkuravimo galimybes. Rusijos gynybos pramonès atstovai bei valdininkai iki šiol linkę laikytis mito, jog Rusija gali gaminti ir tiekti šiuolaikinę ginkluotę gerokai pigiau nei konkurentai iš Vakaru. Nors iki šiol šie teiginiai atitiko tikrovę, tačiau ši pigumą sąlygoja keletas laipsniškai nykstančių faktorių.

Dauguma įmoniu šiuo metu naudojasi dar sovietiniais laikais sukurtomis ginkluotès technologijomis, kurios atiteko nemokamai, todèl nereikèjo investuoti lèšu joms sukurti. Lygiai taip pat didžioji dalis pramonès įrengimų bei kitu materialinių fondų buvo sukurti iki $1992 \mathrm{~m}$. Antai šiuo metu 80 \% įrangos GPK gamyklose jau yra ties susidèvėjimo riba (kai kurių įmonių įranga neatnaujinta nuo pat šių įmonių įkūrimo $)^{27}$. Naują įrangą teks pirkti jau už savo lèšas pasaulinèmis kainomis.

Reikalingu gamybai žaliavų kainos taip pat jau seniai susilygino su pasaulinėmis, vienintele išimtimi lieka žemos energetinių resursų ir elektros energijos kainos, kadangi jas vis dar dotuoja Rusijos Vyriausybė. Tačiau ir jos nuolat auga.

Pastebètina, kad vis sudetingiau pasinaudoti ir pigios darbo jègos faktoriumi, nepaisant to, jog darbo užmokestis Rusijos GPK yra kur kas mažesnis nei Vakarų konkurentu, jis pastaruoju metu visą laiką sparčiai auga, kadangi gynybos pramone priversta konkuruoti dèl darbo jẻgos su kitomis ūkio šakomis (vidutinis mėnesio atlyginimas Rusijoje jau pasiekè 290 USD ribą). Be to, aukščiausios kvalifikacijos darbuotojai dažnai pasirenka emigraciją ar darbą užsienio korporacijose, jų tiriamuosiuose padaliniuose, veikiančiuose Rusijoje, tokiuose kaip „Boeing“ tiriamasis centras Maskvoje ar „Intel“ Nižnij Novgorode, kuriuose dirba šimtai Rusijos specialistų ${ }^{28}$.

Tačiau dar svarbesnis faktorius yra Rusijos GPK struktūros neefektyvumas. Kad ginkluotės gamyba atsipirktų, kad ją būtu galima pardavinèti žemomis kainomis, ji turi būti gaminama ir parduodama dideliu kiekiu. Čia itin iliustratyvu tai, jog Rusijos aviacijos ir raketų - kosmoso pramonëje dirba 800 tūkst. darbuotoju, o analogiškoje šakoje Europos Sajungoje - 98 tūkst., tuo pat metu ES aviacijos pramonė yra 10 kartų didesnè nei Rusijos (22 prieš 2,2 mlrd. USD) ${ }^{29}$.

Šiuo metu net santykiškai didelès eksporto apimties į Kiniją ar Indiją nepakanka, kad Rusijos įmonėms atsipirktu ginkluotės gamyba, jei ši ginkluotė būtų naujai sukurta, o ne senų dar SSSR ginkluotės pavyzdžių modifikacijos.

\footnotetext{
${ }^{27}$ „Российская оборонная промышленность деградирует“, http://www.aviaport.ru/news/2004/ 09/29/84086.html.

${ }_{28}^{28}$ Леонов О., ,,Intel «украдет» российских ученых“, РБК-Дэйли, http:/ /www.rbcdaily.ru/news/ company/index.shtml?2004/01/22/50347.

29 ,Потемкинский комплекс в ВПК“, Итоги, 20030411.
} 
Kai kurių ekspertu nuomone, net esant tokioms lengvatinèms sąlygoms Rusijos gynybos pramoné parduoda šią ginkluotę beveik už savikainą.

Tuo pat metu, kai naujausi karinès pramonės gaminiai yra tiekiami eksportui, Rusijos kariuomene yra priversta tenkintis pasenusia technika. Rusijos Generalinio štabo inspektoriaus M.Moisejevo duomenimis ${ }^{30}$, Rusijos Ginkluotosiose pajėgose šiuolaikinès kartos ginkluotès dalis sudaro ne daugiau nei $20 \%$, tuo pat metu tik $10 \%$ ginkluotés yra ne senesné nei 10 metu.

Tokia situacija, kaip bebūtų keista, irgi mažina ir Rusijos gamintojų eksporto galimybes. Pagaminta naujoviška ginkluotė nėra patikrinama realiomis Rusijos kariuomenès naudojimo sąlygomis, todèl potencialūs jos trūkumai dažnai taip ir lieka nežinomi, kol ji nėra patiekiama užsakovams. Todèl per pastaruosius 15 metų itin padaugëjo pretenzijų iš užsienio pirkẻjų. Taip pat nemaža dalis potencialių pirkëjų bijo pirkti karinę techniką, kurios nenaudoja net pati Rusijos kariuomenè.

O ar Rusijai apskritai ekonomiškai apsimoka eksportuoti ginkluotę? Iš vienos pusès tai suteikia galimybes merdinčiai gynybos pramonei bent šiaip taip išgyventi. Tačiau iš ginklų eksporto gaunami 5,9 mlrd. USD bendrų dabartinės Rusijos užsienio prekybos viršpelnių (kai bendras eksportas viršija 180 mlrd. USD) fone yra itin menki.

Tokia situacija yra labai palanki dirižistinėms nuotaikoms: reikia pasinaudoti puikia valstybès finansine situacija ir skubiai didinti išlaidas ginkluotei pirkti, tik taip dar įmanoma išsaugoti Rusijos GPK potencialą. Tačiau Rusijos karinės pramonės atveju tokios logikos tinkamumą kvestionuoja pastaruju metu praktika. Nepaisant to, jog išlaidos šiai sričiai vis auga, situacija gerejja itin lètai.

Rusijos kariniu pirkimu biudžetas, kaip ir visos gynybos išlaidos, nuo 1999 m. nuolat auga. Antai 2004 m. išlaidos ginkluotei pirkti ir moksliniams tyrimams sudarė $4,5 \mathrm{mlrd}$. USD, o $2005 \mathrm{~m}$. pirmą kartą per pastaruosius metus viršijo ginkluotės eksporto apimtįi ir sudarè $6,5 \mathrm{mlrd}$. USD (kaip jau buvo minèta, eksporto apimtis apie 5,7-5,9 mlrd. USD), o bendros gynybos išlaidos $-18 \mathrm{mlrd}$. USD $^{31}$. Itin spartus išlaidų augimas laukiamas 2006 m., kai karinių pirkimu apimtis sudarys 8,3 mlrd.USD (taigi per metus išaugs $30 \%$ ).

Tačiau Rusijos gynybos pramonės atstovai nèra patenkinti gynybos pirkimų augimu. Kaip jau buvo minėta, nemaža šių lěšų dalis yra investuojama i naujai ginkluotei kurti reikalingus mokslinius tiriamuosius darbus. Tam 2005 m. buvo skirta 2,15 mlrd. USD (33,5\%). Akivaizdu, jog tai logiška, i a ateitị orientuota pozicija. Tačiau lèšos yra investuojamos itin neefektyviai, jos išskaidomos daugeliui skirtingu tyrimo centru, tūkstančiams skirtingų tyrimo projektu, todèl kiekvieno ju poreikiai galu gale tẻra patenkinami $20-40 \%$, taigi užuot vykdę mokslinius tyrimus daugelis mokslinių tiriamujų centrų ir toliau vegetuoja ${ }^{32}$.

\footnotetext{
${ }^{30}$ Путилов С., ,Окончательная армейская распродажа“, Независимое военное обозрение, 20031219.

31 „Никакое реальное военное строительство в России не ведется“, Время новостей, 20050809.

32 Ten pat.
} 
Didelè problema yra tai, jog karinio užsakymo pinigai yra skirstomi labai neskaidriai. Dèl nacionalinio saugumo paskatų oficiali informacija apie tai, kur yra išleidžiamos šios lèšos, slapta. Apie išlaidų struktūrą galima spręsti tik iš atskiru Rusijos pareigūnu bei ekspertu pasisakymu. Didžiuliai sunkiai sukontroliuojami pinigų srautai itin traukia įvairias jų pasisavinimu suinteresuotas grupes. Už šių lešu skirstymą iki 2003 m. buvo atsakinga Gynybos ministerija. Galima spèti, jog nemaža dalis kadrinių pokyčių jos vadovybèje, be kita ko, būdavo susiję ir su kova dèl galimybės skirstyti gynybos išlaidų lèšas.

Pasipiktinęs neefektyviu lěšų panaudojimu ir norèdamas padidinti savo Administracijos įtaką šioje sferoje, V. Putinas nurodè sukurti specialią instituciją - Federalinę gynybos įsigijimų tarnybą (Федеральная служба по оборонному заказу). Vadovauti šiai institucijai $2004 \mathrm{~m}$. pradžioje buvo paskirtas buvęs „,Rosoboroneskport" vadovas A. Beljaninovas, iki tol sẻkmingai vystęs Rusijos ginkluotės eksportą. Naujoji institucija planuoja iggyvendinti skaidrių viešuju pirkimų praktiką šioje srityje, kontroliuoti produkcijos kokybę ir t. t. Bet praktiškai iš karto kilo konfliktų tarp naujosios institucijos ir Gynybos ministerijos padaliniu, kurie piktybiškai neteikè reikiamos informacijos ${ }^{33}$. O ir pati tarnyba yra pavaldi Gynybos ministrui, kas akivaizdžiai neužtikrins planuojamo veiklos efektyvumo.

Strategijų ir technologijų centro ekspertai mano, kad net ir esant dabartinẻms gynybos išlaidoms, jei lèšos būtų naudojamos efektyviau, Rusija galètų sau leisti įsigyti gerokai daugiau naujos ginkluotès, net nemažindama išlaidu moksliniams tyrimams. Šiuos teiginius iliustruoja Rusijos ir Indijos karinių pirkimų palyginimas. Abiejų šalių išlaidos kariniams pirkimams ir moksliniams tyrimams iki $2004 \mathrm{~m}$. buvo panašios (apie 4-5 mlrd. USD per metus). Indija 2002-2004 m. už šias lèšas įsigijo 22 naikintuvus SU-30, 10 prancūziškų naikintuvu Mirage 2000-5, 124 rusiškus tankus T-90C, dvi fregatas ir keletą dešimčių malūnsparnių. O Rusija tesugebejo per tą patị laiką įsigyti 50 tankų T-90C bei suremontavo ar modernizavo po keletą malūnsparniu, naikintuvų ir povandeninių laivų. Tiesa, Rusijos kariuomenè dar ịsigijo 20 atominiu galvučių raketų nešeju „Topol $-\mathrm{M}^{\prime \prime 34}$. Taigi realios išlaidos ginkluotei pirkti, net ir turint omenyje, jog už tas pačias lèšas buvo remontuojama esama karinè technika, Rusijos atveju vargu ar viršijo 2,0-2,5 mlrd. USD.

Nepaisant to, jog ginkluotès pirkimai auga daug léčiau, nei to norètu GPK atstovai, net ir šiu pirkimų planų valstybei įvykdyti nepavyksta. Taip yra todèl, kad gynybos pramonés įmonés nuolat kelia savo produkcijos kainas. Jos kyla greičiau nei bendra infliacija šalies ekonomikoje. Antai vien per $2004 \mathrm{~m}$. bendros Gynybos Pramonès Komplekso prekiu kainos išaugo $32 \%{ }^{35}$. Nepaisant to, jog daugumas įmoniu yra valstybinès ar iš dalies valstybinès, jos naudojasi savo monopoline padètimi. Užuot siekus didesnio efektyvumo einama paprasčiausiu keliu - keliamos kainos. Pastebėtina, jog dažnai kainos, kuriomis

\footnotetext{
${ }_{33}^{33}$ Мухин В., ,Министерство счетной обороны“, Независимая газета, 20051013.

34 ,Первый шаг к спасению (Правительство пытается реанимировать российский авиапром)“, Эксперт, 20040216.

${ }^{35}$ Петров Н., , Качество продукции ОПК приобретает масштаб национальной угрозы“, STRANA.RU, http:/ / www.strana.ru/stories/02/01/16/2353/231002.html .
} 
produkcija parduodama valstybei, yra daug didesnès, nei tiekiant prekes eksportui. Eksporto atveju kontrolè ir kokybės reikalavimai yra kur kas griežtesni ir aiškiai nurodyti kontraktuose. Ir visiškai nepaisoma to, jog analogiški reikalavimai nurodomi ir valstybės pirkimo dokumentuose: gynybos pramonès įmonės teisinasi didejjančiomis žaliavu, energijos ir kitomis išlaidomis. Tokį GPK įmonių savivaliavimą dar labiau skatina tai, jog per $2004 \mathrm{~m}$. né viena tokių įmoniu nebuvo nubausta už tiekimo kontraktų sąlygų nesilaikymą.

Gynybos pramonės funkcionavimui didelę neigiamą įtaką daro Rusijos kariuomenės reformos tikslų neapibrèžtumas. Nepaisant to, jog karinės reformos klausimas yra vienas svarbiausių tiek žiniasklaidoje, tiek politikų retorikoje, paprastai šis aptarimas susiveda į diskusiją apie tai, kaip turi būti formuojama kariuomenè: šauktinių ar kontraktininkų. Tuo pat metu tik iš dalies yra atsakoma ị klausimą, su kokiomis grèsmèmis planuoja kovoti Rusijos kariuomenè ir atitinkamai kokia ginkluotè jai yra reikalinga. Sprendžiant pagal Rusijos kariškių retoriką, jie vis dar gyvena Šaltojo karo sąlygomis ir šiuolaikinį karą mato kaip masinius tankų ir aviacijos mūšius, tuo tarsi ignoruodami pastaruju metų karų tendencijas, kuriuose vis didesnis dėmesys yra teikiamas informacinèms technologijoms, aukšto tikslumo taškinio poveikio ginkluotei ir t. t. Tokia konservatyvi pozicija itin patogi gynybos pramonės atstovams, kadangi ji nereikalauja kardinaliu pokyčių: juk kur kas paprasčiau tobulinti jau gaminamus ginkluotès tipus nei kurti kažką kardinaliai nauja.

\section{GPK reforma: bandymai didinti valstybès įtaką}

$2001 \mathrm{~m}$. Rusijoje vadovaujant tuometiniam vicepremjerui I. Klebanovui buvo pradèta plataus masto gynybos pramonés sektoriaus reforma. Pagrindiniu dokumentu, apibrěžiančiu šios reformos gaires, tapo Federalinė Tikslinė Progama "Gynybos pramonės komplekso reformavimas ir vystymas (2002-2006 metais)“. Pagrindinis reformos siekis - padidinti Rusijos Gynybos Pramonès Komplekso efektyvumą, sukuriant 75 šakinius vertikaliai integruotus holdingus. Kiekvienai ginkluotès rūšiai, pavyzdžiui, naikintuvams, šarvuotajai technikai ir t. t., planuota sukurti po vieną ar kelias (priklausomai nuo ginkluotés tipo) tokias struktūras, kurios savyje sujungtų tiek moksliniu tyrimų centrus, tiek ir gamybines pajègas. Vertikaliai integruotu holdingų sistemą būtu daug lengviau valdyti nei šiuo metu veikiančias daugybę atskiru įmonių. Toks holdingas galètų efektyviai akumuliuoti finansinius resursus ir vykdyti karinès technikos kūrimo gamybos procesą nuo pirmujų eskizų iki galutinio produkto. Reformos koncepcija buvo pasirinkta išanalizavus Vakarų valstybių (visų pirma JAV) patirti. Siuo metu viena iš itin rimtų Rusijos GPK problemų ir yra sutrikęs bendradarbiavimas tarp atskirų šio proceso grandžiu - konstruktorių biurų, komponentų bei galutinio produkto gamintojų. Planuota, jog holdingai sujungs tik maždaug pusę GPK įmonių, likusios neperspektyvios įmonès turès arba užsidaryti, arba pakeisti savo gamybos profili. 
Skirtingai nuo Vakaru (kur praktika įrodè būtent privataus kapitalo efektyvumą), Rusijoje buvo nutarta, jog valstybès nacionalinių interesų vardan būtinas valstybinis vadovavimas šiu koncernų veiklai.

Gynybos pramonės sektoriuje, skirtingai nuo kitų pramonės šaku, 1992$2000 \mathrm{~m}$. nebuvo vykdoma tokio plataus masto privatizacija kaip kitose ekonomikos srityse. Priklausomai nuo vienos ar kitos įmonès svarbos nacionaliniam saugumui, ji buvo arba paliekama visiškai valstybės kontrolei, arba akcionuojama (dažniausiai išlaikant valstybės kontrolę ir paliekant mažiausiai $25 \%$,"blokuojantį" akciju paketą). $2004 \mathrm{~m}$. valstybinės unitarinės įmonės (100 \% priklausančios valstybei) ir akcinès bendrovès, kuriose valstybei priklause dalis kapitalo, sudare $72 \%$ bendro GPK įmonių skaičiaus ir gamino $80 \%$ produkcijos ${ }^{36}$.

Nepaisant to, daugumoje formaliai valstybės kontroliuojamų imoniu visą laiką vyksta kova dèl galimybių kontroliuoti finansinius srautus, ir nors kiekvienoje įmonëje šios kovos pusės skiriasi, paprastai tai yra senoji įmonių valdyba (dažnai dar vadinami „,raudonaisiais direktoriais“), valstybinès institucijos (vietiniai ir federaliniai valdžios subjektai), privačios finansinès grupès ir net nusikalstamos grupuotès. Tokia kova jokiu būdu negerina įmonių ekonominiu rezultatu, o ir taip ribotos pajamos dar labiau ištirpsta dèl korupcinių interesu.

$2001 \mathrm{~m}$. reforma vyksta itin nesėkmingai. Iki $2005 \mathrm{~m}$. vietoje planuotų 60 koncernų tẻra sukurti tik 5 (iki metu pabaigos planuojama sukurti dar keletą). Galima išskirti keletą pagrindinių reformos nesėkmės priežasčių.

Nuolat keičiasi valstybinès institucijos, atsakingos už GPK reguliavimą. Nuo 1992 m. valstybinio reguliavimo sistema keitèsi 7 kartus. Šiuo metu pagrindinè struktūra, koordinuojanti šios pramonės veikla, yra Federalinė pramonės agentūra, kuri įeina į Pramonės ir energetikos ministerijos sistemą. Tokie nuolatiniai pokyčiai ir kova dẻl įtakos sferų tik dar labiau apsunkina ir taip sudètingą Gynybos pramonès situaciją. Pati gynybos pramonè nèra dabartinès Rusijos valdžios ekonominės politikos prioritetas, nepaisant to, jog ir laikoma potencialiu ekonominio augimo lokomotyvu. Kur kas daugiau dėmesio skiriama stojimui į PPO, naftos ir dujų įmonių aktyvu perskirstymui. Kadangi reformoms gynybos pramonëje reikalinga itin didelè politinè valia, o finansų srautai naftos eksporto viršpelnių fone nèra labai žymūs, ši sritis dažnai pamirštama.

Reformos nesèkmes lemia ir itin stiprus šio sektoriaus veikëju pasipriešinimas. Sėkmingai eksporto kontraktų dèka veikiančioms įmonèms įejjimas į holdingo struktūrą reikštų būtinybę dalytis savo uždirbamomis lèšomis su ne tokiais sẻkmingais rinkos žaidèjais, taip pat mažesnę nepriklausomybę, kadangi ką ir kaip gaminti būtų sprendžiama centralizuotai, dažnai pamirštant atskiru įmonių interesus dèl bendrų holdingo interesu.

Reformai taip pat aktyviai priešinasi Rusijos regionų vadovybė, kadangi sukūrus tokias integruotas struktūras jos gali prarasti stambias pajamas iš mokesčiu, kuriuos sumoka regionuose. Vertikaliuose holdinguose finansiniai srautai bus skirstomi per centrines šių holdingų įmones.

36 ,Российская оборонная промышленность деградирует“, http://www.aviaport.ru/news/2004/ 09/29/84086.html. 
Didžiulio pasipriešinimo ši idèja sulaukè iš privačių GPK įmonių. Ju savininkai visiškai nẻra suinteresuoti atiduoti savo valdomas įmones valstybinių koncernų globai. Privatūs savininkai jau ne kartą įrodė, jog sugeba daug efektyviau nei valstybė elgtis su savo aktyvais.

Pastebėtina, kad pačios privačios įmonès kuria alternatyvias vertikaliai integruotas struktūras. Itin būdingas čia NPO „Irkut" pavyzdys. SSSR laikais tai buvo viena iš gamyklu, kurioje buvo vykdoma serijinė naikintuvu „,SU“ gamyba. Naujieji įmonés savininkai suprato, jog toks statusas neužtikrins įmonei sèkmingos ateities. Todèl gamybinès pajejgos buvo papildytos Berievo lèktuvu konstravimo biuru bei įmone, gaminančia avioniokos produkciją. Tokios integruotos struktūros sukūrimas bei efektyvi vadyba leido "Irkut" tapti viena didžiausių Rusijos gynybos pramonės struktūru, kuri pagal eksporto apimtį tris kartus lenkia valstybinę „"MIG“ korporaciją ${ }^{37}$. Apie ketinimus sukurti analogišką integruotą privačią struktūrą pareiškè ir IST grupè, kuriai priklauso Baltijos laivu statykla, be kita ko, gaminanti laivus Indijos rinkai.

Tokie privačių įmonių planai, nepaisant to, jog ekonomiškai yra sẻkmingi, tuo pat metu trukdo valstybės planų vykdymui. Todèl pastebima tendencija didinti valstybės įtaką įmonèse, šiuo metu valdomose privataus kapitalo. Tai gali būti daroma juridiškai iš naujo įvertinus privatizacijos procesą. Rusijos oficialūs asmenys kaip galimybę susigrąžinti įmones valstybès žinion mato intelektualiosios valstybės nuosavybės vertės perskaičiavimą. Jų nuomone, daugumas įmonių praktiškai nemokamai naudojasi SSSR laikais valstybės lèšomis sukauptomis technologijomis bei "know-how", todèl valstybè visiškai teisètai gali reikalauti tinkamo atlygio už šią nuosavybę ${ }^{38}$. Taip pat itin efektyvi poveikio priemonė yra pasirinktinis valstybiniu užsakymų bei eksporto kontraktu dalijimas, atsižvelgiant ị atskiru įmoniu „ppaklusnumo“ lygị.

Rusijos valstybinè eksporto tarpininkè „Rosoboroneksport“ taip pat yra suinteresuota sau pavaldžiu vertikalių integruotų struktūrų kūrimu. 2004-2005 m. ji pradejo aktyvią veiklą kurdama holdingą, jungiantį stambiausias malūnsparniu gamybos įmones.

Iš esmès holdingai yra kuriami kaip atsvaras stambioms Vakarų korporacijoms ir tikimasi, kad jie ateityje taps rimtais pasaulio ekonomikos žaidëjais. Žvelgiant pasauliniais masteliais Rusijos GPK lyderiai, palyginus su savo konkurentais iš Vakaru, yra tikri nykštukai. Autoritetingo JAV savaitraščio Defence News duomenimis, stambiausias Rusijos GPK Koncernas AKH "Sukhoi“ didžiausių pagal pardavimus gynybos pramonès firmų šimtuke teužima 34 vietą (1,5 mlrd. USD), priešraketiniu gynybos kompleksu gamintojas „Almaz - Antei“ -50 (1,3 mlrd. USD), koncernas "Irkut" -66 vietą ( $640 \mathrm{mln}$. USD). Iš viso šiame šimtuke yra 7 Rusijos i̇monès. Tuo pat metu pirmaujančios reitinge amerikiečiu „,Lockheed Martin“ pardavimai sudare 35 mlrd. USD, „Boeing“ - 52 mlrd. (iš jų pagal gynybos užsakymus 30,46 mlrd. USD) ${ }^{39}$.

\footnotetext{
${ }^{37}$ Khazbiev A., „Diversion in the Supply Lines”, Expert, 20040719.

${ }^{38}$ РОСБАЛТ, Полеты во сне и наяву, 20030822.

39 ,Согласно рейтингу Defense News, Концерн ПВО „Алмаз-Антей“ вышел на второе место среди российских производителей оружия“, Военно-промышленный курьер, 20050810.
} 
Tai viena iš priežasčiu, kodèl itin prieštaringai vertinamos ir užsienio investicijos bei bendradarbiavimas su užsienio korporacijomis. Iš vienos pusės, yra akivaizdu, jog kooperacija net ir tokioje jautrioje nacionaliniam saugumui srityje kaip gynybos pramonė yra neišvengiama. Todèl jau ir šiuo metu vykdoma nemažai bendrų projektų su JAV, Prancūzijos, Indijos, Izraelio ir kitų valstybių įmonėmis. Tuo pat metu dirižistams užsienio korporacijos - tai visų pirma konkurentai, kuriu tikslas yra Rusijos karinès pramonės žlugdymas. Taip yra todèl, kad, skirtingai nuo žaliavų sektoriaus, kurị galima integruoti į dabartinę pasaulinę ekonomiką, Rusijos GPK savo šakine struktūra yra itin panaši į Vakarų valstybių GPK. Tuo pat metu Rusijos įmonès dèl savo mažumo lengvai gali tapti stambių užsienio konkurentų grobiu.

Tokius teiginius pagrindžia ir itin nesėkmingos amerikiečių malūnsparnių gamintojos „Sikorskij“ investicijos ị Maskvos "Milio“ malūnsparnių gamyklą, kai užsienio investuotojai visais būdais stengèsi nustekenti savo konkurentą. Užsienio investicijose matomi ir ketinimai pasisavinti dar išlikusį Rusijos GPK technologinį potencialą.

Tendencija riboti užsienio investicijas yra būdinga ne tik GPK, bet Rusijos ekonomikai apskritai. Savo metiniame pranešime Federaliniam Susirinkimui $2005 \mathrm{~m}$. balandị V. Putinas pareiškẻ apie būtinybę juridiškai apriboti užsieniečiu dalyvavimą „,Rusijos saugumui ir nepriklausomybei svarbiuose sektoriuose" (čia, be gynybos pramonès, turètos omenyje ir stambios naftos verslovès bei energetinio sektoriaus įmonès). Tokių sektorių sąrašą planuojama patvirtinti specialiu ịstatymu, kurị Vyriausybe ịpareigota priimti. Šiuo metu didžiojoje dalyje gynybos sektoriaus įmonių užsieniečiams yra draudžiama įsigyti daugiau nei $25 \%$ akciju.

Nepaisant to, jog $2001 \mathrm{~m}$. reforma praktiškai nejuda i prieki, oficialiai ji yra tęsiama. Tai patvirtina ir $2005 \mathrm{~m}$. vasarį Rusijos Prezidento duotas nurodymas kurti Jungtinę aviacijos kompaniją, kuri suvienys didžiąją dalį Rusijos aviacijos pramonès įmonių ir galbūt taps paskutiniu šansu Rusijai suspèti į nuvažiuojantį aviacijos pramonès traukinị.

\section{Vietoje pabaigos: Rusijos GPK perspektyvos}

Apžvelgus Rusijos Gynybos Pramonės komplekso situaciją galime pastebèti, kad giliosios jos problemos, paveldètos dar iš SSSR laiku, yra sprendžiamos tik iš dalies. Tai lemia daugelio struktūrinių problemų tolesnį gilëjimą. Iki šiol vyrauja nuostata, jog šiam sektoriui būtina išskirtinė valstybinè globa ir situaciją ištaisyti gali tik didesnis valstybès finansavimas ir dar didesnè kontrolè. Šiuo metu Rusijos valstybè disponuoja didžiulèmis finansinèmis galimybèmis, kurių panaudojimas galètų itin pagerinti situaciją šioje šakoje, net ir nepaisant didelio šio komplekso neefektyvumo. Tačiau, kaip rodo praktika, net ir finansavimo augimas savaime negarantuoja teigiamų rezultatų. 
Turint omenyje straipsnyje išdejstytus aspektus, galima teigti, jog artimiausiais metais vargu ar galima tikètis žymaus situacijos Rusijos GPK sektoriuje gerëjimo. Nepaisant neblogų atskirų įmonių ir pramonės šakų perspekty$\mathrm{vu}, \mathrm{GPK}$ vargu ar taps visos Rusijos ekonomikos lokomotyvu. Taip yra todèl, kad Rusijos ekonomika susiduria su daugybe vienas už kitą svarbesnių ekonominių iššūkių ir GPK reformavimas yra tik vienas iš jų. Ir kol kas, nepaisant deklaruojamo jo prioritetiškumo, sunku įžvelgti kokybinius situacijos pokyčius.

O Rusijos ekonomikai apskritai kasmet vis sunkiau pasinaudoti galbūt paskutiniais savo šansais tapti aukštujų technologijų ir šiuolaikinės ekonomikos valstybe, o ne toliau grimzti į priklausomybės nuo žaliavų eksporto liūną.

Vilnius, 2005 m. gruodis - 2006 m. sausis 